Article

\title{
Perceptions of Different Stakeholders on Reclaimed Water Reuse: The Case of Beijing, China
}

\author{
Weiping Chen ${ }^{1}$, Yanying Bai ${ }^{2, *}$, Weiling Zhang ${ }^{1}$, Sidan Lyu ${ }^{1}$ and Wentao Jiao ${ }^{1}$
}

1 State Key Laboratory for Urban and Regional Ecology, Research Center for Eco-Environmental Sciences, Chinese Academy of Sciences, Beijing 100085, China;

E-Mails: wpchen@rcees.ac.cn (W.C.); zhangweiling10@mails.ucas.ac.cn (W.Z.); 1vsidan01@163.com (S.L.); wtjiao@rcees.ac.cn (W.J.)

2 Institute of Geographic Sciences and Natural Resources Research, Chinese Academy of Sciences, Beijing 100101, China

* Author to whom correspondence should be addressed; E-Mail: baiyy@igsnrr.ac.cn; Tel./Fax: +86-10-6488-8202.

Academic Editor: Vincenzo Torretta

Received: 25 May 2015 / Accepted: 26 June 2015 / Published: 21 July 2015

\begin{abstract}
Public involvement is critical to the successful implementation of reclaimed water reuse programs. Based on the participatory research method, we studied the attitudes of the stakeholders who are involved in reclaimed water reuse in Beijing, China. Results showed that the general public's knowledge on water resources was poor, while their awareness on reclaimed water reuse was high. The general public showed a strong acceptance of non-contact and non-potable reclaimed water reuse, but their acceptance of the three major water reuse types of river water supplement, park water supplement, and agriculture irrigation was not high. The beneficial use of reclaimed water was admired by water resource managers, industrial sectors, and researchers, and these stakeholders strongly supported the advancement of reclaimed water reuse. However, some of the stakeholders showed concerns about the potential risks from reclaimed wastewater reuse. Among them, risks from waste water treatment facilities were the biggest concern. Stakeholders' perception of reclaimed water was influenced by their social-economic attributes. This study will enrich the current survey findings on public perception of reclaimed water reuse, particularly in developing countries.
\end{abstract}


Keywords: public awareness; stakeholder willingness; wastewater reuse; water resource; risk management

\section{Introduction}

As the urban water shortage grows and water purification technologies advance, municipal wastewater is being reclaimed and reused in increasing volumes and for more purposes around the world [1]. Beijing, China has a successful urban water reuse program. Its annual reclaimed water reuse has risen rapidly from 260 million tons in 2005 to 800 million tons in 2013 [2]. The amount is expected to exceed 1000 million tons by 2015 [3]. The municipality strives to make reclaimed water a key component of the water resource management scheme, accounting for $20 \%$ of the total water supplies.

Besides the public health, environmental, and economical concerns, successful water reuse programs also depend on acceptance and support from the general public [4]. As the ratepayers will be directly impacted and eventually have to pay for the costs, public opposition may potentially be an obstacle to advance reclaimed water reuse projects. In 1994, San Diego (California, USA) proposed that reclaimed wastewater undergo tertiary treatment processes including coagulation-precipitation, granulated activated carbon filtration, microfiltration, and UV disinfection so that the treated water can be used as part of the supply for the city's source water storage reservoir. While the proposal gained the support of technical experts and regulatory approval by the California Department of Health Services, the plan failed to materialize due to public opposition and local politics [5].

The public attitudes toward urban wastewater reuse have been surveyed in the U.S. [5], Australia [6-8], Africa [9], Crete [10], and Thailand [11]. Outcomes of a survey in Israel showed that among 21 reclaimed water reuse options, $95 \%$ of the public supported those with low and intermediate risk of human contact, such as landscape irrigation and fire protection, while less than $15 \%$ of the public supported those with high risk for human contact, such as processing food and recharging potable water aquifers. Despite the seemingly low risk of human contact, merely $50 \%$ of the public in Israel would support irrigating field crops and orchards with reclaimed water [12]. Marks [13] showed that there were high levels of public acceptance of non-potable water reuse in industrial processing, and irrigating golf courses, public parks, and school grounds in five surveyed U.S. and Australian cities. However, the extent of public acceptance varied for non-potable reuse in irrigating vegetable crops and household gardens. For three California cities (Monterey, Irvine, and San Jose), the public acceptance levels varied from $47 \%-74 \%$, while in Sidney, Australia, it exceeded 95\%. The yuck factor, exacerbated by the media's use of ambiguous terms such as "recycled sewage" and "toilet-to-tap" in characterizing reclaimed water, is a significant negative image to augment reclaimed wastewater reuse, especially for potable and agricultural production purposes [14]. Positive information sharing and outreach education activities can increase the public support of water reuse $[5,15,16]$.

As a developing country with a unique culture, the public's perspectives on water reuse in China are difficult to fathom. In the past decades, the general public simply accepted such plans decreed by the authorities. However, after years of modernization and economic expansion, especially rapid development in public media including TV, cell phones, Internet, etc., the general public has become knowledgeable 
and shows greater environmental concerns. While public opposition does not have the same role that it does in regions like California and Australia, the public acceptance and support have become more and more important in successful implementation of the national water reuse policy. The opposition of residents for the reuse of toilet flushing had led to the failure of many community reclaimed water reuse projects [17]. So far, the attitudes of the Chinese general public and professionals on reclaimed water reuse are unclear. In addition, it is unknown how their perception would be affected by socio-economical attributes, and whether or not there is a significant difference between the developed country and developing country, as well as between the western and eastern country.

In this research, we took Beijing as an example to study the attitudes of both the general public and stakeholder professionals towards reclaimed water reuse. Two sets of questionnaires were developed to examine the awareness of different stakeholders on reclaimed water reuse and risk concerns from stakeholder professionals. Factors affecting stakeholders' attitudes on reclaimed water reuse were discussed. This study will also enhance current findings on public perceptions on reclaimed water reuse, especially in developing countries where few studies have been done.

\section{Methodology}

\subsection{Questionnaire Design}

With different sources of knowledge, the attitudes of stakeholders related involved in reclaimed water reuse, including the general public, managers, manufacturers, operators, and researchers, varied greatly. Two sets of questionnaires were developed. One was intended to test the public's knowledge on Beijing's water supplies and reclaimed water reuse, designated hereafter as Questionnaire I. The second was specifically aimed at probing viewpoints of water reuse stakeholder professionals in Beijing, designated hereafter as Questionnaire II. The survey instruments were designed according to the basic principles of and followed the seven-step protocol for formulating social survey questionnaires, which included design preparation, structure plan, pretest, questionnaire evaluation, finalizing a manuscript, appearance design, and coding.

Questionnaire I consisted of three themes, namely perception in water consumption and wastewater generation, cognition in reclaimed water reuse, and willingness to use reclaimed water with 13 , five, and 14 multiple choice questions, respectively in each theme. Among the 32 questions, seven were objective, and 25 were subjective questions in Questionnaire I.

Questionnaire II included three themes on perception, willingness, and risk identification of reclaimed water reuse with three questions in each theme. The questionnaire was designed for the stakeholder professionals, namely administrators/managers of water reuse programs and researchers who specialize in wastewater reclamation and water reuse.

In both questionnaires, demographical attributes of respondents including gender, age, education, occupation, and personal income were recorded.

\subsection{Survey Methodology}

Questionnaire I was aimed at the general public in metropolitan Beijing. Questionnaires were distributed to randomly selected subjects in 14 public areas across the city during May and June, 2013. 
The survey sites covered parks, transportation stops, and housing complexes. The survey was conducted based on the participatory research method. About three quarters of the invited subjects agreed to complete the survey form. In total, 714 questionnaires were collected. The gender, age, education, occupation, and personal income of the subjects are summarized in Table 1. The gender and age distributions of the surveyed population were similar to the demographical profile of Beijing.

Table 1. Socio-economical attributes of surveyed population $(\mathrm{N}=714)$.

\begin{tabular}{|c|c|c|}
\hline \multicolumn{2}{|c|}{ Personal attributes } & \multirow{2}{*}{$\begin{array}{c}\text { Distribution (\%) } \\
42.05\end{array}$} \\
\hline \multirow{2}{*}{ Gender } & Males & \\
\hline & Females & 57.95 \\
\hline \multirow{5}{*}{ Age } & $<25$ & 23.62 \\
\hline & $25-35$ & 28.01 \\
\hline & $35-45$ & 14.29 \\
\hline & $45-55$ & 13.01 \\
\hline & $>55$ & 21.07 \\
\hline \multirow{4}{*}{ Education } & High school or less ( $\geq 12$ years) & 26.38 \\
\hline & College graduates (12-14 years) & 25.51 \\
\hline & University graduates (12-16 years) & 36.30 \\
\hline & Advanced training ( $>16$ years) & 11.81 \\
\hline \multirow{5}{*}{ Occupation } & Unemployed & 18.65 \\
\hline & Company employees & 41.61 \\
\hline & Self-employed households & 9.47 \\
\hline & $\begin{array}{c}\text { Civil servants and enterprise } \\
\text { workers } \\
\end{array}$ & 8.90 \\
\hline & Retired & 21.38 \\
\hline \multirow{5}{*}{$\begin{array}{l}\text { Monthly income in RMB } \\
\text { (Yuan) }\end{array}$} & $<1500$ & 21.59 \\
\hline & $1500-2500$ & 26.54 \\
\hline & $2500-3500$ & 25.04 \\
\hline & $3500-4500$ & 13.49 \\
\hline & $>4500$ & 13.34 \\
\hline
\end{tabular}

Questionnaire II targeted wastewater reclamation and reuse stakeholder professionals in Beijing, including those associated with the Beijing Water Authority, Beijing Drainage Group LTD, Beijing Hydraulic Research Institute, and academic and scientific research entities. Fifty-seven questionnaires were distributed to 10 individuals with management responsibilities, 25 individuals with marketing and operations responsibilities, and 22 individuals with research and development responsibilities, respectively. Fifty-four questionnaires were returned. Each response was followed by in-depth one-to-one interviews and e-mail correspondences for clarification.

\subsection{Data Analysis}

Survey data were tabulated in Microsoft Office Excel format and statistically analyzed using the SPSS software (SPSS 17.0). To obtain the average response of investigated people to a certain subject without distorting the original data, a scale weighting factor was assigned to each category of 
willingness or favor. The weighing factor for the $j^{\text {th }}$ question on willingness to accept reclaimed water was assigned to be 4, 3, 2, and 1 for categories of strongly willing, acceptable, unwilling, and no opinion, respectively. The overall public's intent to the $j^{\text {th }}$ question $\left(W_{j}\right)$ was the weighted average of the responses that:

$$
W_{j}=\frac{\left(S_{j 4} \times 4+S_{j 3} \times 3+S_{j 2} \times 2+S_{j 1} \times 1\right)}{S_{j 1}+S_{j 2}+S_{j 3}+S_{j 4}}
$$

where $S_{j 1}, S_{j 2}, S_{j 3}$, and $S_{j 4}$ represent the number of subjects that answered the $j^{\text {th }}$ question in "no opinion", "unwilling", "acceptable", and "strongly willing" categories, respectively.

Similarly, a five-point scale with weighing factors ranging from " 5 " for strongly in favor to " 1 " for strongly in opposition was used to judge responses of the reclaimed water stakeholder professionals. The overall degree of recognition for the $i^{\text {th }}$ survey question $\left(R_{i}\right)$ is calculated as:

$$
R_{i}=\frac{\left(A_{i 5} \times 5+A_{i 4} \times 4+A_{i 3} \times 3+A_{i 2} \times 2+A_{i 1} \times 1\right)}{A_{i 1}+A_{i 2}+A_{i 3}+A_{i 4}+A_{i 5}}
$$

where $A_{i 1}, A_{i 2}, A_{i 3}, A_{i 4}$, and $A_{i 5}$ represent the number of subjects that answered the $i^{\text {th }}$ question ranging from strongly in favor to strongly in opposition, respectively.

\section{Results and Discussion}

\subsection{Public Awareness on Water Resources and Reclaimed Water Reuse}

According to the survey, the residents of Beijing are cognizant of the city's water supplies and wastewater treatment situations: $75 \%$ of the respondents realize that the city is facing a severe water shortage; $70 \%$ of the respondents are aware of the massive municipal wastewater collection and treatment infrastructures; and $97 \%$ of the respondents recognize the public health hazards and needs of properly treating and disposing of municipal wastewaters (Table 2). However, $76 \%$ of respondents do not know the sources of Beijing's water supply, $60 \%$ do not know the primary generators of Beijing's wastewater, and $97 \%$ do not know which sectors in the city consume the largest volume of water. The public inclines to blame the industrial sector for causing the water shortage and water pollution. Additionally, $42 \%$ and $55 \%$ of the respondents thought industries are the biggest water consumers and the primary sources of municipal wastewater in Beijing, respectively. In reality, Beijing's population of over 20 million residents by default consumes more water and generates a greater volume of wastewater than any other socio-economic sectors. Overall, the public lacks accurate knowledge on the water resources of Beijing and there is room for improvement. 
Table 2. The public's responses to the posted questions on water resources and uses in Beijing.

\begin{tabular}{lll}
\hline Question & Preferred option & Correct option \\
\hline Main water source & Surrounding rivers or reservoirs & Groundwater $(24.47 \%)$ \\
Largest field of water consumption & $(56.16 \%)$ & Industry $(41.57 \%)$ \\
Water shortageor not & Severe water shortage $(75.07 \%)$ & Same as preferred option \\
Main wastewater source & Industrial wastewater $(54.58 \%)$ & Domestic water(39.73\%) \\
Where municipal wastewater goes & Sewage treatment plant $(70.12 \%)$ & Same as preferred option \\
Sewage needs treatment or not & Yes $(97.47 \%)$ & - \\
Household waste water or not & No $(71.07 \%)$ & - \\
Community waste water or not & Yes $(63.59 \%)$ & - \\
Be able to reduce water consumption & Yes $(78.96 \%)$ & - \\
Would like to reduce water & Yes $(81.07 \%)$ & - \\
consumption & Yes $(73.88 \%)$ & - \\
Would like to pay for water treatment & & \\
\hline
\end{tabular}

About $70 \%$ of the respondents feel that domestic consumptions are essential and the users are not responsible for the shortages in the city, but the majority of them feel that they can conserve water (79\%) and would like to reduce water consumption (81\%). Meanwhile, $64 \%$ of respondents hold the viewpoints that public uses such as landscaping irrigation and street cleaning are excessive and wasteful. These findings suggest that there is room for conserving water, the public is not well informed regarding water uses, and their viewpoints about various water users may be biased. As the capital of China, Beijing may represent the optimistic case in public awareness on water resources and reclaimed water reuse. The government has not paid much attention to public outreach until recent years. Thus, public opinions may be distorted by unofficial media.

Water rates may influence domestic water consumption and may be a means to encourage water conservation. The majority of the respondents feel that the current rate is reasonable (40\%) or somewhat high (38\%). A small portion of the respondents view the current rate being either very high $(6 \%)$ or too low $(10 \%)$ (Figure 1a). With increasing water prices in recent years, residents pay more attention to water conservation, and managers of parks and companies show higher interest in using reclaimed water. Water price is critical in expending the water reuse. Currently, the reclaimed water price is kept at $1 \mathrm{RMB}$ per ton, roughly $17 \%$ of that of the city's public water, far from adequate to recuperate capital investments and operation costs of the water reuse system. Reasonable water rates are necessary for promoting water saving and water reuse. 

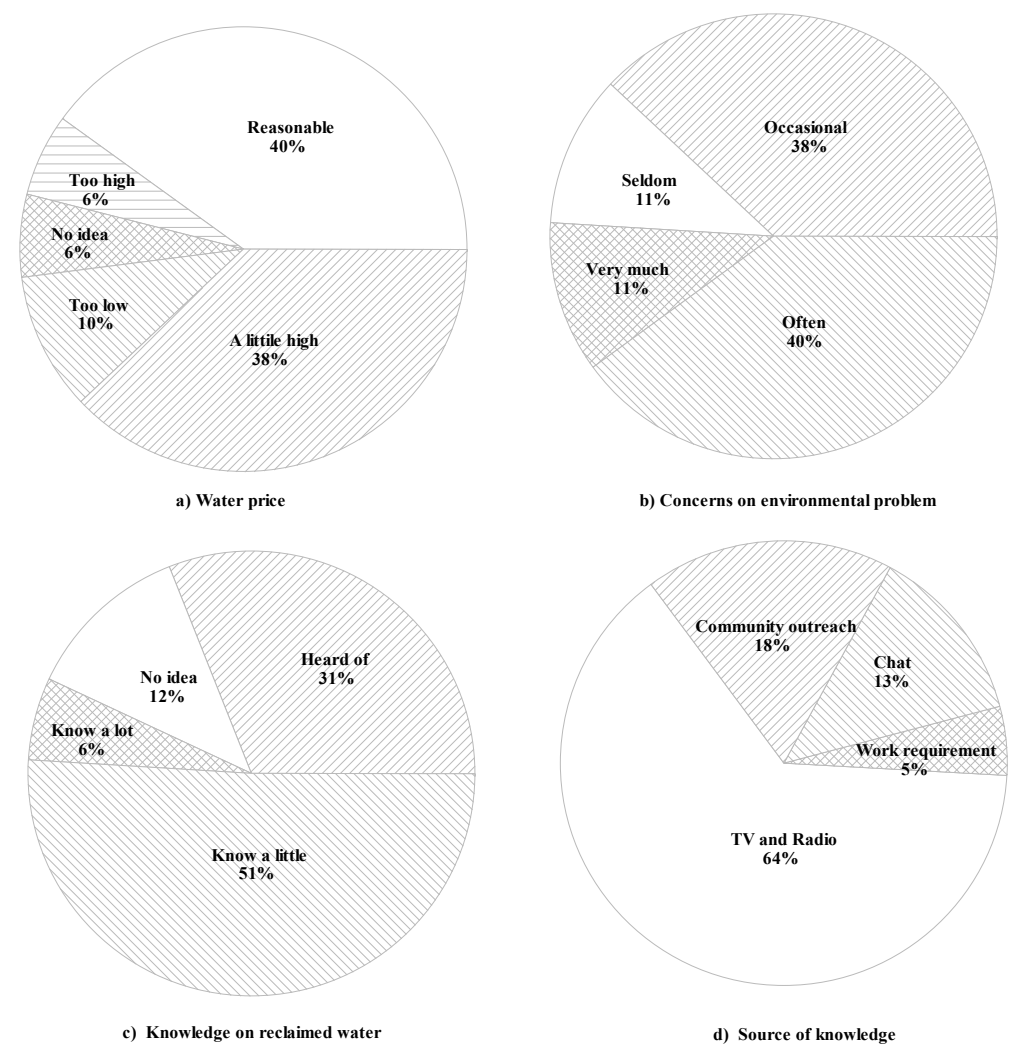

Figure 1. The public's knowledge on water supply and wastewater in Beijing.

Further developments in water resources may cause adverse environmental impacts. Approximately $11 \%$ and $40 \%$ of the respondents express strong and intermediate commitment, respectively, to environmental protection, while $38 \%$ and $11 \%$ of the respondents show successively less enthusiasm toward protecting the environment (Figure 1b). If the public's perspective and consciousness on environmental protection becomes more favorable, it may be an incentive in promoting the water conservation and reclaimed wastewater reuse.

Beijing over the years has made great efforts to disseminate information on water reuse. The overall public awareness on water reclamation is high. About $90 \%$ of the respondents are aware of the ongoing wastewater reclamation and reuse (Figure 1c) and point to the fact that reclaimed water may be used for toilet flushing, car washing, landscape irrigation, etc. The majority of the respondents $(64 \%)$ acquired the knowledge through public information messages from television and radio media. Less effective, though, $18 \%, 13 \%$, and $5 \%$, of the respondents, respectively, learned about water reuse through community outreach, personal contacts, or other means (Figure 1d).

The individual's willingness to accept non-body contact and non-potable reuse of the reclaimed wastewater is overwhelming (Table 3). Over $90 \%$ of the respondents are willing to accept or strongly endorse reclaimed water for toilet flushing, fire protection, landscape irrigation, street cleaning, industrial cooling, ornamental lakes, and car washing. Even crop irrigation and domestic uses (except for drinking and food preparation) are acceptable to $82 \%$ of respondents. Collectively, the support based on the aggregated willingness scores according to Equation (1) ranges from 3.51 to 3.04, between the score of 4 for strongly agree and the score of 3 for acceptable. The public is less enthusiastic about the potentially potable reuse options, especially for supplementing the domestic water supply, which is deemed unacceptable by $63.3 \%$ of the respondents. 
Table 3. The public's acceptance of reclaimed water reuse options.

\begin{tabular}{|c|c|c|c|c|c|c|}
\hline Reuse Category & & $\begin{array}{c}\text { Strongly } \\
\text { agree }(\%)\end{array}$ & $\begin{array}{c}\text { Acceptable } \\
(\%)\end{array}$ & $\begin{array}{c}\text { Unwilling } \\
\text { (\%) }\end{array}$ & $\begin{array}{c}\text { No } \\
\text { comment } \\
(\%) \\
\end{array}$ & $\begin{array}{c}\text { Aggregated } \\
\text { willingness } \\
\text { factor }^{\text {(a) }} \\
\end{array}$ \\
\hline \multirow{10}{*}{$\begin{array}{l}\text { Non-body } \\
\text { contact and } \\
\text { non-potable } \\
\text { reuses }\end{array}$} & Toilet flushing & 63.17 & 29.84 & 1.6 & 5.39 & 3.51 \\
\hline & Firefighting & 59.24 & 34.93 & 0.58 & 5.24 & 3.48 \\
\hline & $\begin{array}{l}\text { Landscape } \\
\text { irrigation }\end{array}$ & 58.22 & 35.66 & 0.58 & 5.53 & 3.47 \\
\hline & Street cleaning & 59.68 & 32.31 & 2.18 & 5.82 & 3.46 \\
\hline & $\begin{array}{l}\text { Industrial cooling } \\
\text { water }\end{array}$ & 57.93 & 35.08 & 1.31 & 5.68 & 3.45 \\
\hline & $\begin{array}{l}\text { Landscape } \\
\text { fountain }\end{array}$ & 55.17 & 36.54 & 3.2 & 5.09 & 3.42 \\
\hline & Car cleaning & 55.9 & 33.19 & 6.26 & 4.66 & 3.4 \\
\hline & $\begin{array}{l}\text { Park water } \\
\text { supplement }\end{array}$ & 46.29 & 40.47 & 8.01 & 5.24 & 3.28 \\
\hline & $\begin{array}{l}\text { Agriculture } \\
\text { irrigation }\end{array}$ & 42.07 & 40.17 & 14.12 & 3.64 & 3.21 \\
\hline & $\begin{array}{l}\text { Non-potable and } \\
\text { non-cooking } \\
\text { domestic uses }\end{array}$ & 26.93 & 56.48 & 10.04 & 6.55 & 3.04 \\
\hline \multirow{3}{*}{$\begin{array}{l}\text { Potentially } \\
\text { potable reuses }\end{array}$} & $\begin{array}{l}\text { River flow } \\
\text { supplement }\end{array}$ & 44.69 & 35.08 & 16.3 & 3.93 & 3.21 \\
\hline & $\begin{array}{l}\text { Groundwater } \\
\text { recharge }\end{array}$ & 34.93 & 35.37 & 24.6 & 5.09 & 3.00 \\
\hline & $\begin{array}{l}\text { Supplementing } \\
\text { drinking water } \\
\text { supply }\end{array}$ & 8.44 & 25.04 & 63.32 & 3.2 & 2.39 \\
\hline Average & & 28.09 & 61.43 & 7.42 & 3.06 & 3.15 \\
\hline
\end{tabular}

Overall, the extent of Beijing residents' willingness to accept reclaimed wastewater reuse in their community is remarkable. The results were in line with other findings that willingness to reuse appears as a descending trend as reclaimed water use transits from public to private $[8,14,18,19]$. Improving renewable water quality and expanding the knowledge-related publicity are effective ways to increase the degree of willingness to use recycled water.

\subsection{Perception of Stakeholder Professionals on Reclaimed Water Reuse}

The stakeholder professionals including managers, producers and operators, and researchers are overwhelmingly positive about the reclaimed water reuse. Among them, 81\% strongly believe the benefits of water reuse and the remaining $19 \%$ of the respondents feel that the reclaimed water reuse is acceptable (Figure 2a). They overwhelmingly (96\% of the respondents) support technology advancements of wastewater reclamation (Figure 2c). On the prospect of reclaimed water (Figure $2 b$ ), 
the responses are: $50 \%$ strongly confident, $46 \%$ slightly optimistic, $2 \%$ unsure, and $2 \%$ pessimistic about the future of water reuse.
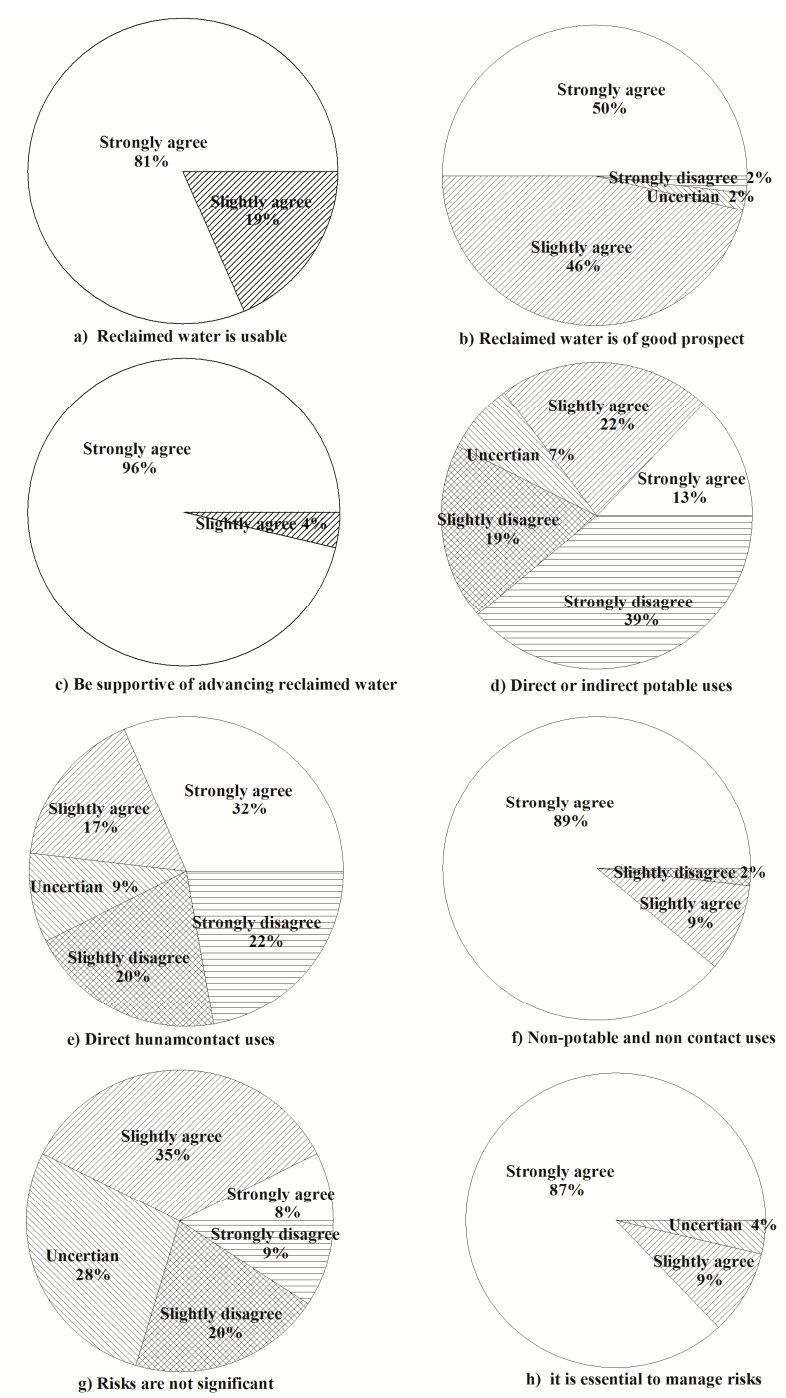

Figure 2. Reponses of Beijing's water reuse professionals to questions on recycling reclaimed water.

We employed a 1-to-5 scale to probe the aggregate viewpoints of professionals on water reuse with 5 being strongly in favor and 1 being strongly in disagreement (Table 4). From the professional point of view, the stakeholders understand the critical need for developing new water resources for Beijing and collectively feel that recycling reclaimed wastewater is beneficial for the city (aggregate score $=4.78$ ). They are optimistic toward the official water reuse program (aggregate score $=4.44$ ), and support advanced technology developments for recycling water (aggregate score $=4.95$ ). In comparison to manufacturers and operators, researchers were more optimistic on reclaimed water reuse, which may be due to their closer contact with the latest environmental developments and their good understanding about the urgency of water scarcity and pollution. The reason that manufacturers and operators had lower confidence in the future of reclaimed water reuse may be because they were quite familiar with the current situation of water reuse and promotion in Beijing, knowing the difficulty of advancing reclaimed water very well. 
Table 4. Average degree of recognition and willingness of different stakeholder professionals on reclaimed water.

\begin{tabular}{lcccc}
\hline Question & Manager & $\begin{array}{c}\text { Manufacturer and } \\
\text { operator }\end{array}$ & Researcher & Mean value (a) \\
\hline Reclaimed water is usable & 4.60 & 4.73 & 5.00 & 4.78 \\
Reclaimed water is of good prospect & 4.50 & 4.27 & 4.55 & 4.44 \\
Be supportive of advancing reclaimed water & 4.90 & 5.00 & 4.95 & 4.95 \\
Risks are not significant & 3.70 & 2.68 & 3.27 & 3.22 \\
It is essential to manage risks & 5.00 & 4.73 & 4.86 & 4.86 \\
Direct or indirect potable uses & 3.50 & 2.27 & 2.32 & 2.70 \\
Direct human contact uses & 3.90 & 3.32 & 2.64 & 3.28 \\
Non-potable and non-touching uses & 4.60 & 4.95 & 4.86 & 4.81 \\
\hline
\end{tabular}

Notes: (a) Calculated by Equation (2).

The stakeholders of water reuse programs incline to favor non-body contact and non-potable reuse options, and avoid those having the potential risk implications of potable reuse (Figure $2 \mathrm{~d}-\mathrm{f}$ ). The managers, producers and operators, and researchers exhibit different perspectives on cost effectiveness, system performances, and environmental sustainability [11]. Those in managerial positions who are promoting and implementing the policies tend to be more optimistic and are willing to push the water reuse programs further, especially for body-contact and potentially potable reuses. The researchers, producers, and operators who are at the frontlines dealing with research and development issues and reuse process routines tend to be more cautious and considerably less enthusiastic of the body-contact and potable reuses (Table 4$)$.

\subsection{Perception on Risks Associated with Reclaimed Water Reuse}

Stakeholders are aware of the public health and environmental pollution risks that come along with water reuse, and view risk control as essential in the implementation and management of water reuse projects (Table 4). Furthermore, $43 \%$ of the stakeholder respondents feel that health and environmental risks are not significant issues, with the remainder divided between those uncertain of the risks and those who view the risks as being serious (28\%vs. 29\%) (Figure $2 \mathrm{~g}$ ), and the overwhelming majority of the respondents (87\%) agree that steps to minimize risks are imperative (Figure $2 \mathrm{~h}$ ).

The water reuse program in Beijing is unique in that the effluents of the municipal wastewater treatment systems are through a contractual agreement turned over and sold to a revenue-supported intermediary entity, which is solely responsible for upgrading and marketing the reclaimed water to users across the city. The stakeholder respondents identify four areas in the water reuse programs where potential public health and environmental risks may arise (Table 5). Additionally, 66\% of the respondents are concerned that reclaimed water producers and marketers often fail to deliver the water of promised quality to the downstream. Risks may also stem from the inappropriate uses by those acquiring the reclaimed water (an issue raised by $59 \%$ of the respondents) and inadequate quality controls during the course of quality upgrading operations (an issue raised by $54 \%$ of the respondents). Finally, the conveyance and storage stage of reclaimed wastewater may also result in contamination due to cross connections, leakages, and accidental spills (an issue raised by $41 \%$ of the respondents). Judging from 
the responses, although the water reuse stakeholder professionals in Beijing are committed to the idea of reusing reclaimed wastewater, they are not entirely comfortable with the reliability and effectiveness of the wastewater treatment and reclaimed water marketing operations that are the backbone of a successful reuse program (Table 5). These results are closely related with stakeholders' roles in water reuse development and their understandings of water reclamation.

Table 5. Sources of public and environmental risks of using reclaimed water in Beijing, according to the opinions of local water reuse professionals.

\begin{tabular}{|c|c|c|c|}
\hline Source & Responded Positive (\%) & Cause & $\begin{array}{c}\text { Responded } \\
\text { Positive (\%) }\end{array}$ \\
\hline \multirow{2}{*}{ Wastewater } & \multirow{2}{*}{66} & Origin of wastewater & 83 \\
\hline & & Treatment efficiency and reliability & 48 \\
\hline \multirow{2}{*}{ End uses } & \multirow{2}{*}{59} & Quality of reclaimed water & 72 \\
\hline & & End use categories & 46 \\
\hline \multirow{3}{*}{ Production/operation } & \multirow{3}{*}{54} & Treatment technology & 83 \\
\hline & & Accidental spills & 44 \\
\hline & & Equipment malfunction & 35 \\
\hline \multirow{3}{*}{ Conveyance and storage } & \multirow{3}{*}{41} & Cross-connection & 59 \\
\hline & & Pipeline leakage and corrosion & 46 \\
\hline & & Backflow & 19 \\
\hline
\end{tabular}

\subsection{Factors Affecting Public and Stakeholders Awareness on Reclaimed Water Reuse}

The general public and stakeholder professionals' responses to different survey questions are affected by their social-economic backgrounds (Table 6). Occupation is a significant factor (at $p<0.01$ ) for the general public in correctly answering three of the six questions about knowledge of Beijing's water resources. Those holding public sector jobs appear to pay more attention to such activities than those working in the private sectors or who are self-employed. The respondent's awareness of the water resource issues is also significantly affected (at $p<0.01$ ) by age, income, and education factors. Older, higher-income, and well-educated individuals are better informed and have more reasonable expectations of what the water supply system can deliver to them. Gender does not appear to affect the outcomes.

The general public's viewpoints on how water is used throughout the city are divided (at $p<0.01$ or $p<0.05$ significant levels) by age, gender, occupation, income, and education factors. Older, less-educated, female, and self-employed respondents tend to feel that water is being wasted across the spectrum. Older respondents (at $p<0.01$ ) especially feel that there is room for water conservation in the city. When asked to reduce their water consumption, the female (at $p<0.01$ ), higher-earning (at $p<0.05$ ), and more educated (at $p<0.05$ ) respondents are more willing to participate than the others. Again, older (at $p<0.01$ ), more educated (at $p<0.01$ ), higher-income (at $p<0.01$ ), and public sector (at $p<0.01$ ) respondents are concerned more about the environmental impacts of water resource development and express greater willingness to pay for the water. The younger, less educated, and lower-income respondents appear to be indifferent one way or the other in terms of water reuse. 
Table 6. Social-economic factors that affected views on water reuse.

\begin{tabular}{|c|c|c|}
\hline Category & Question & $\begin{array}{l}\text { Significant Demographic } \\
\text { Factor (a) }\end{array}$ \\
\hline \multirow{6}{*}{$\begin{array}{l}\text { Public's knowledge } \\
\text { on water resources }\end{array}$} & Regarding to Beijing's water sources & Age $* *$ Occupation $* *$ \\
\hline & $\begin{array}{l}\text { Regarding to water consumption trends in } \\
\text { Beijing }\end{array}$ & None \\
\hline & Regarding to Beijing's water shortage & $\begin{array}{l}\text { Education ** Occupation ** } \\
\text { Income } * *\end{array}$ \\
\hline & $\begin{array}{l}\text { Regarding to Beijing's wastewater production } \\
\text { trends }\end{array}$ & Occupation $* *$ Education $*$ \\
\hline & Where does municipal wastewater go? & Income * \\
\hline & Do municipal wastewater need treatment? & Age * \\
\hline \multirow{7}{*}{$\begin{array}{l}\text { Public's opinion on } \\
\text { water uses }\end{array}$} & Is your household wasting water? & None \\
\hline & Is Beijing wasting water? & $\begin{array}{l}\text { Age *, Occupation *, } \\
\text { Education* }\end{array}$ \\
\hline & Can Beijing's water consumption be reduced? & Age $* *$ \\
\hline & Would you like to reduce water consumption? & $\begin{array}{l}\text { Gender ** Education * } \\
\text { Income* }\end{array}$ \\
\hline & Are you willing to pay for water treatment? & $\begin{array}{l}\text { Income ** Education * } \\
\text { Occupation } *\end{array}$ \\
\hline & $\begin{array}{l}\text { Are you concerned about environment } \\
\text { problems? }\end{array}$ & Age $* *$ Occupation $* *$ \\
\hline & Is the water rate high? & Age ** Education ** Income ** \\
\hline \multirow{2}{*}{$\begin{array}{l}\text { Public's perception } \\
\text { on reclaimed water }\end{array}$} & $\begin{array}{l}\text { Are you aware of the reclaimed water reuse in } \\
\text { Beijing? }\end{array}$ & $\begin{array}{l}\text { Education } * * \text { Income } * * \\
\text { Occupation } *\end{array}$ \\
\hline & Where do you get the information from? & Age ** Occupation * Income * \\
\hline \multirow{5}{*}{$\begin{array}{l}\text { Public's } \\
\text { willingness to use } \\
\text { reclaimed water }\end{array}$} & Drinking water supplement & Age $* *$ Income $* *$ \\
\hline & River supplement/Groundwater recharge & Age * \\
\hline & Non-potable household uses/firefighting & Income $* *$ Education $*$ \\
\hline & $\begin{array}{l}\text { Park water supplement/agriculture } \\
\text { irrigation/car cleaning }\end{array}$ & Income * \\
\hline & $\begin{array}{l}\text { landscape irrigation/road cleaning/public } \\
\text { toilet flushing/industrial cooling } \\
\text { water/landscape fountain }\end{array}$ & Education $* *$ Income $* *$ \\
\hline \multirow{3}{*}{$\begin{array}{l}\text { Stakeholder's } \\
\text { perception on } \\
\text { reclaimed water }\end{array}$} & Role of reclaimed water & $\begin{array}{l}\text { Education ** Income ** } \\
\text { Gender* }\end{array}$ \\
\hline & Prospect of reclaimed water & Education * Occupation * \\
\hline & Support of reclaimed water & - \\
\hline \multirow{2}{*}{$\begin{array}{l}\text { Stakeholder's } \\
\text { opinions on risks of } \\
\text { reclaimed water } \\
\end{array}$} & Risk significant or not & Occupation $* *$ Age $* *$ \\
\hline & Build-up of risk management system & - \\
\hline \multirow{3}{*}{$\begin{array}{c}\text { Stakeholder's } \\
\text { willingness to } \\
\text { reclaimed water } \\
\text { reuses }\end{array}$} & Non-potable and non-touching uses & - \\
\hline & Direct touching uses & Income * \\
\hline & Direct or indirect potable uses & Occupation * \\
\hline
\end{tabular}

Notes: ${ }^{(a)}$ Linear correlation between the response of each investigation participant and their demographic factor was conducted. Statistical inferences: $*$ and ${ }^{* *}$ denote the factor earmarked is correlated to the question at $p<0.05$ and $p<0.01$ significant levels, respectively. 
Allowed to choose how the reclaimed water would be used, the respondents have strong preferences toward non-body contact and non-potable water reuse options (Table 6). Respondents with higher incomes, more education, and who are older (age 35 to 55) are more optimistic about the future of water reuse, but they are less supportive of the riskier potable reuse options. A survey from the San Diego County Water Authority showed that there was a shifting of public opinion on the potable reuse of reclaimed wastewater between 2004 and 2011. Those who "strongly oppose" using reclaimed water that has received advanced treatment to augment the drinking water supply dropped from $45 \%$ in 2004 to $11 \%$ in 2011 [20] through unyielding public outreach efforts. Beijing undoubtedly must wage credible outreach efforts to convince the population to embrace water reuse.

The water reuse professionals are more realistic and practical in terms of the roles of reclaimed wastewater in Beijing. Their perceptions and expectations are less likely to be influenced by social-economic factors such as personal income, gender, and occupation. However, the technical knowledge (reflected in the education levels) and experience (reflected in the age factor) are significant factors (Table 6). This group occupies the management and technical decision-making positions in the water reuse programs. As a result, despite the official policy push to implement water reuse, the implementation approach has been cautious and progress has been slow.

\section{Conclusions}

Reclaimed water reuse is a national policy and Beijing has the largest-scale and most successful water reuse program in China by far. We investigated attitudes of both the general public and professionals towards reclaimed water reuse in Beijing. The outcomes reveal that: (1) The majority of the respondents, although keenly aware of the water shortages and quality issues, have misconceptions about the city's sources of water supply, the biggest consumers of pubic water supplies, and the biggest generators of wastewater in the community; (2) most residents consider themselves conscious in conserving water resources yet there is room for water conservation because others are wasting water (nonetheless, they are willing to reduce their water consumption); and (3) respondents are knowledgeable about wastewater reclamation and are strongly willing to use reclaimed water except for potable use. Nonetheless, the respondents shy away from supporting augmenting river flows, groundwater recharge, and directly or indirectly augmenting the public water supplies. In all, the residents of Beijing are willing to accept reclaimed water, but their knowledge needs to be improved through targeted information dissemination coupled with properly set water rates to promote water conservation and encourage water reuse.

The survey of water reuse professionals showed that: (1) Beijing's water reuse professionals recognize the positive roles that reclaimed water may play in the city's water supply and they strongly support technological development to promote water reuse, yet a few of them are pessimistic about the future of recycling reclaimed wastewater; (2) the overwhelming majority of the professionals hold the opinion that risk aversion and management are imperative in reclaimed water reuse; and (3) they are aware of risks that may arise at the reclaimed wastewater treatment and production phases due to upstream water quality issues, operation errors, equipment failures, and accidental spills, or at the utilization phase due to cross connections and mismatches of uses and water quality. 
The general public's and stakeholder professionals' perceptions on reclaimed water reuse are affected by their social-economic backgrounds. It is necessary to improve stakeholders' understanding of reclaimed water in order to smooth the implementation of water reuse.

\section{Acknowledgments}

We acknowledge the research supports provided by the National Natural Science Foundation of China (41271501) and National Key Technology Support Program (2012BAC13B04).

\section{Author Contributions}

Weiping Chen analyzed the data and completed the first draft, Yanying Bai designed the questionnaires and revised the manuscript, Weiling Zhang \& Sidan Lv collected the data, Wentao Jiao made the graphs and went through the manuscript.

\section{Conflicts of Interest}

The authors declare no conflict of interest.

\section{References}

1. Chen, W.P.; Lu, S.D.; Jiao, W.T.; Wang. M.E.; Chang, A.C. Reclaimed water: A safe irrigation water source? Environ. Dev. 2013, 8, 74-83.

2. Yi, L.L.; Jiao, W.T.; Chen, X.N.; Chen, W.P. An overview of reclaimed water reuse in China. J. Environ. Sci. 2011, 23, 1585-1593.

3. Chang, D.H.; Ma, Z. Wastewater reclamation and reuse in Beijing: Influence factors and policy implication. Desalination 2012, 297, 72-78.

4. Wu, D.; Zhao, Y.; Pei, Y.S.; Geng, H. Proposes on utilization and management of reclaimed wastewater in China. Water Resour. Hydropower Eng. 2010, 41, 10-14.

5. Hartley, T.W. Public perception and participation in water reuse. Desalination 2006, 187, 115-126.

6. Hurlimann, A.; Mckay, J. Urban Australians using recycled water for domestic non-potable use-An evaluation of the attributes price, saltiness, colour and odour using conjoint analysis. J. Environ. Manag. 2007, 83, 93-104.

7. Dolnicar, S.; Schäfer, A.I. Desalinated versus recycled water: Public perceptions and profiles of the accepters. J. Environ. Manag. 2009, 90, 888-900.

8. Dolnicar, S.; Hurlimann, A.; Grun, B. What affects public acceptance of recycled and desalinated water? Water Res. 2011, 45, 933-943.

9. Adewumi. J.R.; Ilemobade, A.A.; VanZyl, J.E. Treated wastewater reuse in South Africa: overview, potential and challenges. Resour. Conserv. Recy. 2010, 55, 221-231.

10. Menegaki, A.N.; Hanley, N.; Tsagarakis, K.P. The social acceptability and valuation of recycled water in Crete: a study of consumers' and farmers' attitudes. Ecol. Econ. 2007, 62, 7-18.

11. Nitirach, S.N.; Vilas, N. Strategic decision making for urban water reuse application: A case from Thailand. Desalination 2011, 268, 141-149. 
12. Friedler, E.; Lahav, O.; Jizhaki, H.; Lahav, T. Study of urban population attitudes towards various wastewater reuse options: Israel as a case study. J. Environ. Manag. 2006, 81, 360-370.

13. Marks, J.S. Taking the public seriously: The case of potable and non-potable reuse. Desalination 2006, 187, 137-147.

14. Miller, G.W. Integrated concepts in water reuse: managing global water needs. Desalination 2006, 187, 65-75.

15. Alhumoud, J.M.; Behbehani, H.S.; Abdullah, T.H. Wastewater reuse practices in Kuwait. Environmentalist 2003, 23, 117.

16. Tsagarakis, K.P.; Georgantzis, N. The role of information on farmer's willingness to use recycled water for water for irrigation. Water Sci. Tech. W. Sup. 2003, 3, 105-113.

17. Ma, D.C.; Xu, L.W. Study on current situation and public policy of water reclamation and reuse in Beijing. Heilong Jiang Sci. Technol. Water Conserv. 2005, 33, 71-73.

18. Hurlimann, A. Melbourne office worker attitudes to recycled water use. Water J. Aust. Water Assoc. 2006, 33, 58-65.

19. Mckay, J.; Hurlimann, A. Attitudes to reclaimed water for domestic use. J. Aust. Water Assoc. 2003, 30, 45-49.

20. U.S. Environmental Protection Agency (USEPA). Guidelines for water reuse, 2012. Available online: http://www.watereuse.org/government-affairs/usepa-guidelines/ (accessed on 14 January 2015).

(C) 2015 by the authors; licensee MDPI, Basel, Switzerland. This article is an open access article distributed under the terms and conditions of the Creative Commons Attribution license (http://creativecommons.org/licenses/by/4.0/). 